\title{
Antibodies to Escherichia coli 0157 in patients with haemorrhagic colitis and haemolytic uraemic syndrome
}

\author{
H CHART, S M SCOTLAND, H R SMITH, B ROWE \\ From the Division of Enteric Pathogens, Central Public Health Laboratory, Colindale, London
}

SUMMARY Twenty four sera from patients with haemolytic uraemic syndrome or haemorrhagic colitis and healthy controls were examined for antibodies to the lipopolysaccharide (LPS) of Escherichia coli 0157 . Faecal specimens from these patients were also examined for Vero cytotoxin producing $E$ coli (VTEC) by DNA probes, and for faecal Vero cytotoxin. Eight patients with faecal $E$ coli $0157: \mathrm{H} 7$ gave a strong antibody response to 0157 LPS, shown by immunoblotting and an enzyme linked immunosorbent assay. Six symptomatic patients without evidence of faecal VTEC also gave a strong antibody response to 0157 LPS. Sera from the remaining five patients and five healthy controls did not contain antibodies to $E$ coli 0157 .

The results suggest that the testing of sera from patients with haemorrhagic colitis or haemolytic uraemic syndrome by ELISA or immunoblot would prove valuable in addition to the established procedures for detecting VTEC, using DNA probes and testing for faecal Vero cytotoxin.

Vero cytotoxin producing strains of Escherichia coli (VTEC) have been associated with cases of haemorrhagic colitis (HC) and haemolytic uraemic syndrome (HUS).$^{1-6}$ Although VTEC belonging to serogroups other than 0157 , such as $026,055,0128$ and 0145 , have been implicated in cases of $\mathrm{HC}$ and $\mathrm{HUS},{ }^{47}$ serogroup 0157 is the most prevalent. ${ }^{1-6}$ In a recent study $79 \%$ of VTEC isolated from sporadic cases of HUS belonged to serogroup 0157 , usually $\mathrm{H}$ type 7 but occasionally non-motile. ${ }^{4}$ The detection of $E$ coli $0157: H 7$, other VTEC, and "free" VT in faeces has facilitated the investigations of $\mathrm{HC}^{2}$ DNA probes have been prepared for both types of Vero cytotoxin gene (VT1 and VT2) and have been used for the preliminary detection and characterisation of VTEC. ${ }^{489}$ Strains of 0157:H7 are unable to ferment sorbitol rapidly, and sorbitol MacConkey agar has been developed on which they grow as colourless colonies. This has been used as a simple rapid means of screening stool cultures for $E$ coli $0157: H 7$. Colourless colonies may be confirmed as $E$ coli 0157 using an antiserum raised to the 0157 O-antigen. ${ }^{1011}$

VTEC, and the toxins they produce, are usually only detectable in faecal specimens for a limited period of time following the onset of symptoms of disease. ${ }^{3-5}$ An alternative means of detecting evidence of infection by $E$ coli 0157 is to detect serum antibodies, and

Accepted for publication 20 April 1989 this would prove particularly useful for diagnosis late in disease. In a previous study we showed that sera from patients with HUS, from whom $E$ coli $0157: H$ had been isolated, contained IgG antibodies recognising OMP A and other outer membrane proteins, and also high concentrations of IgM antibodies specific for the lipopolysaccharide (LPS) of E coli 0157 . Patients' sera could be distinguished from those of healthy control sera based on this serological response. ${ }^{12}$ In the present study we compared the qualitative and quantitative immune response of patients with HUS with confirmed $E$ coli $0157: H 7$ infection with patients with symptoms of HUS but from whom evidence of VTEC infection was not demonstrable by either isolation of VTEC or of "free" faecal Vero cytotoxin. Our aim was to establish an immunological test which might be used to diagnose infection with $E$ coli 0157 . Such a test would be useful where these bacteria or their toxins could not be detected in the faeces or when diagnosis was made too late for faecal examination.

\section{Material and methods}

Nineteen human sera obtained from patients with clinically diagnosed HUS or HC were received by the Division of Enteric Pathogens (table). Control sera were obtained from four healthy adult men and 1 healthy adult woman. Seven of the sera from patients with HUS, the serum from the female volunteer, and two sera from the male volunteers have been described 
Table Evidence of $E$ coli 0157 in patients with HUS or HC compared with healthy controls

\begin{tabular}{|c|c|c|c|c|c|}
\hline \multirow{3}{*}{$\begin{array}{l}\text { Source of sera }(n=) \\
\text { Patients with }(n=8) \text { HUS or HC }\end{array}$} & \multirow{3}{*}{$\begin{array}{l}\text { Faecal } V T \\
3 / 7\end{array}$} & \multirow{3}{*}{$\begin{array}{l}V T \text { probes* } \\
8 / 8\end{array}$} & \multirow{3}{*}{$\begin{array}{l}\begin{array}{l}\text { E coli } 0157 \\
\text { isolated }\end{array} \\
8 / 8\end{array}$} & \multicolumn{2}{|c|}{ Antibodies to 0157 LPS: } \\
\hline & & & & \multicolumn{2}{|c|}{ by immunoblot* by ELISA } \\
\hline & & & & $8 / 8$ & \multirow{4}{*}{$\begin{array}{l}x=1.01+0.37(0.50,0.66,0.80,0.88) \\
(1.06,1.19,1.29,1.66) \\
x=1.07+0.37(0.41,1.00,1.06) \\
(1.14,1.33,1.48) \\
x=0.19+0.03(0.15,0.16,0.19) \\
(0.22,0.22) \\
x=0.28+0.07(0.19,0.24,0.26) \\
(0.35,0.36)\end{array}$} \\
\hline Patients with ( $n=6)$ HUS & $0 / 5$ & $0 / 6$ & $0 / 6$ & $6 / 6$ & \\
\hline Patients with $(\mathrm{n}=5)$ HUS or HC & $0 / 4$ & $0 / 5$ & $0 / 5$ & $0 / 5$ & \\
\hline Controls $(n=5)$ & ND & ND & ND & $0 / 5$ & \\
\hline
\end{tabular}

No positive/No tested.

ND: not determined.

previously. ${ }^{12}$ Strains of $E$ coli $0157: \mathrm{H} 7$ were identified as described elsewhere. ${ }^{13}$ Stool samples, when available from the above patients, were examined for VTEC using DNA probes ${ }^{14}$ and faecal VT. ${ }^{4}$

Escherichia coli strain E32511, a non-motile strain belonging to serogroup 0157 , was used to prepare

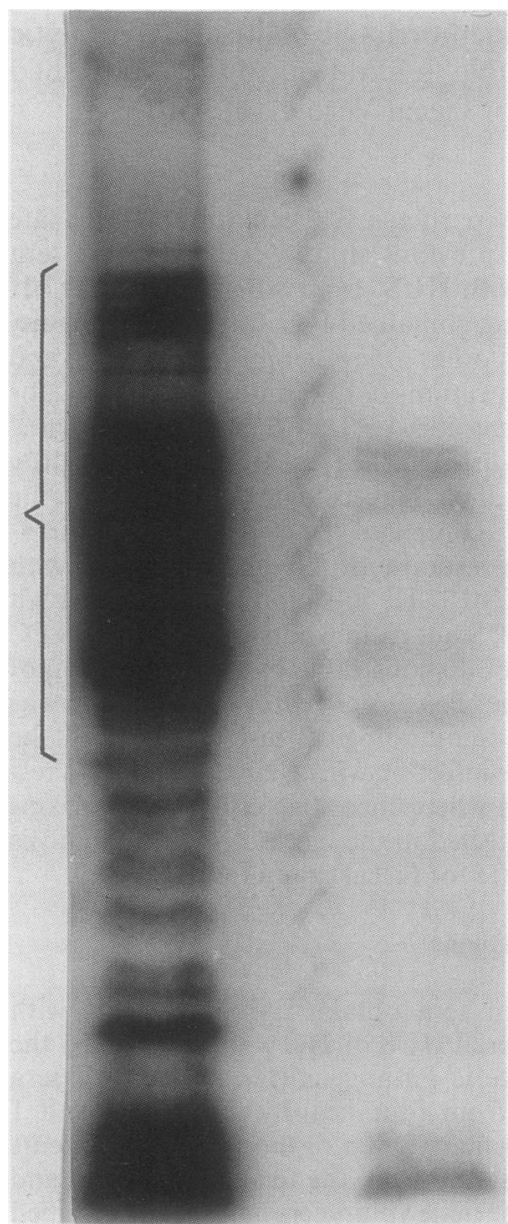

Figure $S D S$ -

$P A G E$ profiles of E coli 0157

(30 $\mathrm{\mu g} /$ lane $)$ reacted strongly with sera 1-14 (an example shown in lane 1), but not with sera 15-25 (an example shown in lane 2). The predominant reaction of antisera was with LPS (in parentheses). bacterial outer membranes and LPS.'2 Bacterial proteins and LPS were separated by sodium dodecyl sulphate-polyacrylamide gel electrophoresis (SDSPAGE) ${ }^{15}$ using a constant current $(50 \mathrm{mAmp}$ ) for three and a half hours. For immunoblotting, outer membrane SDS-PAGE profiles were transferred on to nitrocellulose sheets and reacted with antisera $(30 \mu \mathrm{l} /$ lane), as described previously. ${ }^{12}$ Antibody-antigen complexes were detected using ${ }^{125}$ iodinated goat antihuman IgM antibodies. LPS for enzyme linked immunosorbent assays (ELISA) was prepared from strain E32511 using hot phenol. ${ }^{16}$ ELISA plates were coated with $100 \mu \mathrm{l}$ LPS $(6 \mu \mathrm{g} / \mathrm{ml})$ in coating buffer (1.59 $\mathrm{g} \mathrm{Na}_{2} \mathrm{CO}_{3} / 1,2.39 \mathrm{~g} \mathrm{NaHCO}_{3} / \mathrm{l}, \mathrm{pH} \mathrm{9.6)}$. One hundred microlitre volumes of serum diluted $(\times 1000)$ in phosphate buffered saline containing $0.1 \%$ Tween20 (PBS-Tween), were reacted with LPS coated wells for two hours. Antibody-antigen complexes were detected by reacting plates with an alkaline phosphatase conjugated goat-anti-human Ig antiserum (diluted in PBS-Tween according to the manufacturer's specification, Sigma Chemical Co) for two hours before the addition of p-nitrophenol phosphate $(1 \mathrm{mg} / \mathrm{ml}$, Sigma $)$ in diethanolamine buffer $(97 \mathrm{ml}$ diethanolamine, $100 \mathrm{mg} \mathrm{MgCl}_{3} \cdot 6 \mathrm{H}_{2} \mathrm{O} /$ litre, $\mathrm{pH} 9 \cdot 8$ ). After 30 minutes' incubation in the dark, the reaction was stopped by the addition of $50 \mu \mathrm{l} 3 \mathrm{M} \mathrm{NaOH}$ and the resultant yellow colour measured at $405 \mathrm{~nm}$.

\section{Results}

Faecal samples were obtained from 16 of 19 patients with symptoms of HUS or HC, and faecal swabs were received from the remaining three patients. Faeces and faecal swabs were examined for VTEC and the 16 faecal specimens examined for Vero cytotoxin. Faecal specimens from seven patients (one with HC, seven with HUS) and a faecal swab from one patient contained VTEC, as detected by gene probes; and three out of these seven faecal specimens had detectable Vero cytotoxin (table). E coli $0157:$ H7 was isolated from these eight patients. VTEC were not 
obtained from the remaining 11 patients (one with HC, 10 with HUS), and "free" Vero cytotoxin was not detected in any of the faecal specimens (table).

Twenty four sera, comprising 19 from the aforementioned patients, and five from healthy control subjects, were reacted with replicate outer membrane profiles from strain E32511 by immunoblotting. Fourteen sera gave a reaction with $E$ coli 0157 LPS (table; figure, lane 1). The remaining 10 sera, including the five control sera, gave no reaction with these profiles (table; figure, lane 2). These 24 sera were also reacted with purified 0157 LPS by ELISA. Sera from the eight patients, from whom $E$ coli $0157:$ H7 had been isolated (table), gave a mean antibody titre of $1.01(+0 \cdot 37)$. Sera from six patients with HUS, but giving negative Vero cytotoxin probe and faecal Vero cytotoxin results, gave a mean antibody titre of $1.07(+0 \cdot 37)$. The remaining five sera, from patients with HUS or HC, but giving negative Vero cytotoxin or faecal Vero cytotoxin results, gave a mean titre of $0.19(+0.03)$. Five control sera gave a mean titre of $0.28(+0.07)$.

Using Student's $t$ test, the antibody titres for sera, from patients from whom $E$ coli $0157: H 7$ had been isolated, were found to be significantly higher $(p=0.005)$ than the titres obtained with control sera, but not significantly different from the six sera from patients with clinical HUS but with no evidence of VTEC infection (table). The antibody titres for the five sera, from patients with clinical HUS but from whom evidence of $E$ coli 0157 had not been detected, were significantly different from the other HUS or HC sera $(p=0.005)$, but not from the healthy control sera.

\section{Discussion}

The eight patients (one with HC, seven with HUS), from whom $E$ coli $0157: \mathrm{H} 7$ was isolated, contained high titre serum antibodies (IgM) to the LPS of $E$ coli 0157. Analysis by immunoblotting or ELISA showed that the five control sera did not contain antibodies to $E$ coli 0157 LPS. This suggests that screening sera for antibodies to 0157 LPS might be used to indicate $E$ coli 0157 infection. The six patients with HUS who had high antibody titre to 0157 LPS but no faecal VTEC or Vero cytotoxin might also have been infected with $E$ coli $0157: \mathrm{H7}$. Strains of $E$ coli $0157: \mathrm{H} 7$ are often implicated in cases of HUS and HC, ${ }^{1349}$ but are only isolated from a proportion of patients. ${ }^{13}$ Based on our studies, screening patients' sera for antibodies to the LPS of $E$ coli 0157 might prove useful in indicating a possible pathogenic role for $E$ coli 0157 in such cases.

Our studies showed that the most specific means of analysing sera for antibodies to $E$ coli $0157: \mathrm{H} 7$ was immunoblotting which provided an accurate qualitative antibody reaction. Due to the experimental procedures entailed in this technique, however, immunoblotting may not be suitable for most routine clinical laboratories. The ELISA also provided an efficient means of detecting serum antibodies to $E$ coli 0157 LPS, and in contrast to immunoblotting, has the advantage of requiring only basic laboratory equipment and an ELISA reader. The ELISA, which provides quantitative data, allows a value for delineating antibody titres obtained from patients with an $E$ coli 0157 infection to be distinguished from the sera of those who have not been infected by this organism. Using a cut-off value of $0.5(405 \mathrm{~nm})$ for sera diluted 1000-fold, all patients with confirmed $E$ coli $0157:$ H7 infection were included, and would have been correctly diagnosed as having been infected by $E$ coli 0157 . All six patients negative for VTEC and faecal VT also gave a strong immunoblot reaction, and five would have been regarded as having had an $E$ coli 0157 infection based on the ELISA result alone. The remaining 10 sera, which gave negative ELISA immunoblot reactions, would not have been regarded as having had an $E$ coli 0157 infection. An ELISA could be used as a convenient method for the preliminary screening of large numbers of sera from patients with HUS or HC and the results obtained could be considered in light of the patients' clinical symptoms. In the event of patients with very obvious symptoms of HUS or HC giving a serum ELISA value of $<0.5$, analysis of these sera by immunoblot should be considered.

Because VTEC belonging to serogroups other than 0157 have been isolated from cases of HUS, ${ }^{47}$ the possibility of screening sera for antibodies to the LPS of such VTEC is currently under investigation.

This limited study shows that immunoblotting and ELISA techniques have very similar sensitivities for detecting antibodies to the LPS of $E$ coli 0157 . The use of DNA probes as a sensitive method for the detection of VTEC has been clearly established. ${ }^{49}$ Because immunoblotting tests identified 14 of 19 patients and ELISA tests 13 of 19 patients as having been infected by $E$ coli 0157 , as opposed to eight of 19 by DNA probes, serological tests should be considered as a means of supplementing established diagnostic tests for $E$ coli 0157 infections, particularly when the investigation occurs some time after onset of symptoms.

We thank colleagues for sending sera and faecal specimens to the Division of Enteric Pathogens.

\section{References}

1 Johnson WM, Lior H, Bezanson GS. Cytotoxic Escherichia coli 0157:H7 associated with haemorrhagic colitis in Canada. Lancet 1983;i:76.

2 Karmali MA, Steele BT, Petric M, Lim C. Sporadic cases of 
hemolytic uremic syndrome associated with fecal cytotoxin and cytotoxin-producing Escherichia coli in stools. Lancet 1983;i:619-20.

3 Riley LW, Remis RS, Helgerson SD, et al. Hemorrhagic colitis associated with a rare Escherichia coli serotype. $N$ Engl J Med 1983;308:681-5.

4 Scotland SM, Rowe B, Smith HR, Willshaw GA, Gross RJ. Vero cytotoxin-producing strains of Escherichia coli from children with haemolytic uraemic syndrome and their detection by specific DNA probes. J Med Microbiol 1988;25:237-43.

5 Riley LW. The epidemiologic, clinical, and microbiological features of hemorrhagic colitis. Ann Rev Microbiol 1987;41: 383-407.

6 Smith HR, Scotland SM. Vero cytotoxin-producing strains of Escherichia coli. J Med Microbiol 1988;26:77-85.

7 Karmali MA, Petric M, Lim C, Fleming PC, Arbus GS, Lior H. The association between idiopathic hemolytic uremic syndrome and infection by Verotoxin-producing Escherichia coli. J Infect Dis 1985;151:775-82.

8 Scotland SM, Willshaw GA, Smith HR, Rowe B. Properties of strains of Escherichia coli belonging to serogroup 0157 with special reference to production of Vero cytotoxins VT1 and VT2. Epidemiol Infect 1987;99:613-24.

9 Smith HR, Rowe B, Gross RJ, Fry NK, Scotland SM. Haemorrhagic colitis and Vero cytotoxin producing Escherichia coli in England and Wales. Lancet 1987; i:1062-5.

10 Kleanthous H, Fry NK, Smith HR, Gross RJ, Rowe B. The use of sorbitol MacConkey agar in conjunction with a specific anti- serum for the detection of Vero cytotoxin-producing strains of Escherichia coli 0157. Epidemiol Infect 1988;101:327-35.

11 March SB, Ratnam S. Sorbitol-MacConkey medium for detection of Escherichia coli 0157:H7 associated with hemorrhagic colitis. J Clin Microbiol 1986;23:869-72.

12 Chart H, Scotland SM, Rowe B. Serum antibodies to Escherichia coli 0157:H7 in patients with hemolytic uremic syndrome. J Clin Microbiol 1989;27:285-90.

13 Gross RJ, Rowe B. Serotyping of Escherichia coli In: Sussman M, ed. The Virulence of Escherichia coli. London: Society for General Microbiology, Special Publication No 13, 1985:345-63.

14 Willshaw GA, Smith HR, Scotland SM, Field AM, Rowe B. Heterogeneity of Escherichia coli phages encoding Vero cytotoxins: comparison of cloned sequences determining VTl and VT2 and development of specific gene probes. J Gen Microbiol 1987;133:1309-17.

15 Laemmli UK. Cleavage of structural proteins during the assembly of the head of bacteriophage T4. Nature (Lond) 1970;227: $680-5$.

16 Westphal O, Jann K. Bacterial lipopolysaccharide: Extraction with phenol-water and further application of the procedure. Methods in Carbohydrate Chemistry 1965;5:83-91.

Requests for reprints to: Dr H Chart, Central Public Health Laboratory, Division of Enteric Pathogens, 61 Colindale Avenue, London NW9 5HT, England. 